\title{
DETERMINATION OF INITIAL CHARACTERISTICS OF FUEL COMPONENTS DROPLET CLOUD DERIVED FROM IN-FLIGHT EXPLOSION OF CARRIER ROCKET
}

Institute of Technical Mechanics of the National Academy of Sciences of Ukraine and the State Space Agency of Ukraine,15, Leshko-Popel Str., Dnepr, Ukraine, 49005, e-mail: office.itm@nas.gov.ua

The methodical approach to the determination of the initial kinematics and geometrical characteristics of the fuel components droplet cloud derived from the liquid-propellant carrier rocket (CR) explosion at the atmospheric trajectory leg is developed. The phenomenological analogy of the transient-load damage processes in the fractured solids and a mass of a gas-saturated cavitation liquid is taken as a basis of the approach. The droplet cloud characteristics obtained by this means can be used as the reference data for calculating the subsequent transformation of the cloud when it moves in the gravitation field taking into account heat-mass exchange with an atmosphere, as well as for estimating the ecological risks in the ground area of the CR fallout.

Keywords carrier rocket, explosion, gas-saturated fuel components, fragmentation, dispersion, droplet cloud.

1. Safety of Critical Infrastructures: Mathematical and Engineering Methods of Analysis and Support. Edited by V. S. Kharchenko. Kharkov: NAKU "KhAI", 2011. 641 p.

2. Zheleznyakov A. B. Secrets of Rocket Disasters. Moscow: EKCMO Yauza, 2004. 544 p.

3. Tsutsuran V. I., Petrukhin N. F., Gusev S. A. Military and Technical Analysis of State and Prospects of Development of Rocket Propellants. Moscow: MORF, 1999. 332 p.

4. Aleksandrov E. P. About behavior of droplets of rocket propellant in the atmosphere. Meteorologia i Gidrologia. 1993. No 4. P. $36-45$.

5. Arkhipov V. A., Berezinov A. P., Tkachenko A. S., Usanina A. S. Generalized model of propagation of a liquid-droplet cloud in accident releasing aircraft fuel. Izvestia Vuzov. Fizika. 2010. No 12/2. P. 10-13.

6. Adushkin V. V., Kozlov S. I., Petrov A. V. Environmental Problems and Risks of Effects of Rocket and Space Technology on the Environment. Moscow: Mashinostroenie, 2000. 640 p.

7. Shurshalov P. V. In-flight explosion. Izvestia AN SSSR. MZhG. 1984. No 5. P. 126-129.

8. Surzhikov S. T. Prediction and analysis of extreme effects: materials and coatings under extreme conditions. Look at the future. Vol. 1. Edited by S. V. Reznik. Moscow: Publishing House of MGTU im. N. E. Baumana, 2002. P. 157-172.

9. Belikov V. V., Goloviznin V. M., Semenov V. N. et al. Model of convective ascent of additives ejected in the atmosphere while explosive energy releasing. Izvestia RAN. Energetika. 2000. No 5. P. 128-133.

10. Bondar M. A., Degtyarenko P. G., Kremena A. P., Sviridenko H. F. In-flight explosion of a launch vehicle: environmental impacts and their assessments. Tekhnicheskaya Mekhanika. 2014. No 3. P. 48-57.

11. Biryukov G. P., Smirnov V. I. Elements of the Theory for Designing Rocket and Space Complexes. Moscow: Publishing House of MAI, 2003. 288 p.

12. Stebnovsky S. V., Chernobaev N. N. Effects of Dynamic Loads of Liquid Volume on its Failure Mechanism. PMTF. 1987. No 5. P. 134-139.

13. Explosion Physics. Edited by L. P. Orlenko. Vol. 2 Moscow: Nauka, 2004. 656 p.

14. Lavrentyev M. A., Shabat B. V. Problems of Hydrodynamics and their Mathematical Models. Moscow: Nauka, $1973.416 \mathrm{p}$.

15. Gorban V. P. Study, Development and Introduction of Explosive Sheet Forming Aeronautic Structural Parts: Cand. Sc. (Eng.) Thesis. Kharkov, 1974. 122 p.

16. Gamera Yu. V., Ovcharov $S$. V. Model of formation and propagation of initial air impact wave in highpressure equipment damage. Bezopasnost Truda v Promyshlennosti. 2012. No 12. P. $74-78$.

17. Kopyt N. Kh., Struchaev A. I., Krasnoshchekov Yu. I. et al. Burning large volumes of dispersive fuels and evolution of their products in a free atmosphere. FGV. 1989. No 3. P. $21-28$.

18. Gostintsev Yu. A., Matveev Yu. S., Nebogatov V. Ye., Solodovnik A. F. About physic modelling turbulent terms. PMTF. 1986. No 3. P. $21-28$.

19. Bader V., Donaldson A., Hardy H. Model of fire in damage of liquid rocket. VRT. 1972. No 9. P. 17 - 26

20. Gavrilov G. N., Egorov A. A., Korovin S. K. Electric and Pulse Technology for Mining Art and Civil Engineering. Moscow: Nedra, 1991. $127 \mathrm{p}$.

21. Pokrovsky V. N., Arakcheev Ye. P. Sewage Treatment for Thermal Power Station. Moscow: Energia, 1980. $256 \mathrm{p}$.

22. Prisnyakov V. F. Physics for Boiling. Kiev: Naukova Dumka, 1988. 240 p.

23. Leighton T. G. The acoustic bubble. London: Academic Press, 1994. 633 p.

24. Koshelev E. A., Kuznetsov V. M., Sofronov S. T., Chernikov A. G. Statistics for solid fragments resulting from explosion. PMTF. 1971. No 2. P. 87 - 100.

25. Isaev A. P. Hydraulics of Sprinklers. Moscow: Mashinostroenie, 1973. $216 \mathrm{p}$.

26. Gelfand B. Ye., Gubin S. A., Kogarko S. M. Variety of droplet crushing in impact waves and their characteristics. IFZh. 1974. Vol. 27. No 1. P. $119-126$. 
27. Timoshenko V. I. Theoretical Fundamentals of Engineering Gas Dynamics: Handbook. Kiev: Naukova Dumka, 2013. 431 p. 